Фармацевтична технологія, біофармація, гомеопатія Pharmaceutical technology, biopharmacy, homeopathy

Рекомендована д. фрармац. наук, профр. Т. А. Грошовим

УДК 615.1; 615.453 .6

DOI 10.11603/2312-0967.2017.4.8343

\title{
ВАЛІДАЦІЯ ВИРОБНИЦТВА ТАБЛЕТОК «УРОНЕФРОН»
}

\author{
() В. Л. Шевіна ${ }^{1}$, Н. В. Хохленкова ${ }^{2}$, М. І. Борщевська ${ }^{1}$, В. А. Коноваленко ${ }^{1}$ \\ ПАТ «Фармак» ${ }^{1}$, Київ \\ Національний фрармацевтичний університет ${ }^{2}$ Харків \\ v.shevina@farmak.ua
}

\begin{abstract}
Мета роботи. Надати документальні докази, які підтвердять, що процес виробництва препарату «Уронефрон» у срормі таблеток, вкритих плівковою оболонкою, приводить до отримання продукту встановленої якості.

Матеріали і методи. Валідаційні дослідження проводили на 3 серіях препарату. Валідація процесу виробництва таблеток «Уронефрон» проведена на всіх стадіях технологічного процесу з визначенням критичних параметрів, а саме: підготовка сировини, отримання маси для таблетування, зберігання таблетмаси, таблетування, нанесення плівкової оболонки на таблетки-ядра.

Результати й обговорення. Для визначених критичних параметрів технологічного процесу отримання продукту проводили валідаційні випробування, які дозволяють визначити допустимі межі відхилення цих параметрів.

Результати проведення валідаційних випробувань на кожній стадії технологічного процесу виготовлення таблеток «Уронефрон» відповідають критеріям прийнятності.

Висновок. Валідація процесу виробництва таблеток «Уронефрон» підтвердила кваліфрікацію виробничого персоналу і дотримання ним прописаних параметрів; показала, що технологічне обладнання ділянки в змозі забезпечити відтворюваність параметрів технологічного процесу виробництва, що призводить до очікуваного рівня якості напівпродукту і готової продукції; продемонструвала відтворюваність і стандартність показників якості напівпродукту і готової продукції відповідно до нормативної документації.
\end{abstract}

Ключові слова: валідаційні випробування; критерії прийнятності; технологічний процес; таблетки «Уронефррон».

Вступ. Проведення валідації та ревалідації технологічних процесів є обов'язковою частиною Належної виробничої практики та вимагається чинними нормативними документами 1. У п. 25 Додатку 15 вказаного документа рекомендується обсяг валідаційних робіт проводити для трьох послідовних серій/ циклів препарату в межах остаточно узгоджених параметрів. У майбутньому процеси і процедури слід піддавати періодичній критичній ревалідації, щоб гарантувати, що вони зберегли здатність приводити до очікуваних результатів. Також слід здійснювати періодичну оцінку технічних засобів, систем, обладнання і процесів для підтвердження того, що вони продовжують функціонувати затвердженим чином. Наведені вище вимоги пояснюють актуальність питання валідації процесів [2].

Стандарти та керівні документи свідчать, що частина вимог GMP, виконання яких буде гарантувати, що технічні засоби, допоміжні системи, обладнання, технологічні процеси, аналітичні методики постійно будуть забезпечувати випуск і контроль готової продукції згідно з затвердженими специфрікаціями, міститься в проведенні валідації [2, 3].

Дотримання встановлених умов виробництва нестерильних лікарських засобів $€$ запорукою отримання якісної продукції та забезпечення безпеки спожи- вачів. Одним із критеріїв, що впливає на якість препаратів, $є$ автоматизація процесів виробництва. Це дозволяє максимально виключити людський фрактор при проведенні технологічного процесу. Проведення валідації технологічних процесів призводить до оптимізації параметрів, можливості автоматизувати процес та $є$ необхідним заходом при переведенні препарату на ділянку, сертифріковану за GMP.

Ефективно організована валідація технологічних процесів за міжнародними стандартами $\epsilon$ обов'язковою складовою життєвого циклу виробництва лікарських засобів, одним із процесів у системі управління якістю сучасних фрармацевтичних компаній та поєднує у собі підходи, що викладені у правилах Належної виробничої практики (GMP) та стандартаx ISO серії 9000 [1, 3, 4]. Вона спрямована, в першу чергу, на отримання продукції гарантованої якості, доведеної ефективності та встановленої безпеки $[5,6,7,10]$. Валідація технологічних процесів відповідно до вимог належної виробничої практики проводиться з метою підтвердження, що процес, дії персоналу та фрункціонування систем, які забезпечують даний технологічний процес, повною мірою відповідають призначенню та дозволяють отримати очікувані результати. Валідація є процесом (діяльністю), що триває протягом всього життєвого циклу продукту

ISSN 2312-0967. Pharmaceutical review. 2017. № 4 
Фармацевтична технологія, біофармація, гомеопатія Pharmaceutical technology, biopharmacy, homeopathy

і забезпечує гарантовану якість продукту з урахуванням усіх можливих змін, що виникають з часом [11].

Дослідження 3 валідації повинні сприяти належній виробничій практиці; їх слід проводити відповідно до встановлених методик. Результати і висновки мають бути запротокольовані. Якщо вводять нову виробничу рецептуру або спосіб виготовлення, то мають бути виконані дії, які демонструють їхню придатність для рутинного (серійного) виробництва. Має бути доведено, що встановлений процес при використанні специфрікованих матеріалів і обладнання дозволяє постійно одержувати продукцію необхідної якості. Істотні зміни виробничого процесу, включно будь-яку зміну обладнання або матеріалів, що може вплинути на якість продукції та/або відтворюваність процесу, мають пройти валідацію [1].

Тому проведення валідації технологічного процесу виробництва таблеток «Уронефрон» $€$ необхідним заходом постановки лікарського засобу на виробництво.

Метою нашої роботи було надати документальні докази, які підтвердять, що процес виробництва препарату «Уронефррон» у фрормі таблеток, вкритих плівковою оболонкою, приводить до отримання продукту встановленої якості.

Для досягнення даної мети в рамках валідації процесу слід було: оцінити стандартність і відтворюваність критичних параметрів технологічного процесу; підтвердити, що дотримання технологічних параметрів виробничих операцій, встановлених під час розробки, послідовно і відтворено забезпечує прийнятний рівень якості напівпродукту і готової продукції; продемонструвати, що вплив несприятливих фракторів (ризиків) на якість і безпеку вироблених лікарських засобів мінімізовано; розслідувати і обґрунтувати можливі відхилення.
Виробництво таблеток «Уронефррон», що випускаються на підприємстві, здійснюється в класі чистоти D. Захист продукту від контамінації досягається: 1) під час зважування сировини - односпрямованим потоком повітря; 2) при транспортуванні продукту 3 контейнера в устаткування - щільним з'єднанням контейнера з обладнанням; 3) при прямому контакті з матеріалом обладнання під час технологічного процесу - підбором матеріалу обладнання; 4) відсутністю рециркуляції повітря з приміщень з імовірним підвищеним пилоутворенням; 5) під час прямого контакту продукту з повітрям - фрінішним очищенням повітря фрільтрами.

Сировина, пакувальні матеріали, що використовуються у виробництві лікарського засобу, проходять щосерійний вхідний контроль. На стадії фрармацевтичної розробки нами було виділено критичні параметри технологічного процесу, на підставі яких було проведено валідацію технологічного процесу таблеток «Уронефррон», вкритих плівковою оболонкою.

Матеріали і методи. Валідаційні дослідження проводили на 3 серіях препарату. Валідацію процесу виробництва таблеток «Уронефрон» проведено на всіх стадіях технологічного процесу 3 визначенням критичних параметрів, а саме: підготовка сировини, отримання маси для таблетування, зберігання таблетмаси, таблетування, нанесення плівкової оболонки на таблетки-ядра (табл. 1). Для виробництва таблеток «Уронефрон» використовуються контейнерний змішувач Bin Blender 3 ємностями (бінамі), виготовлені 3 нержавіючої сталі AISI 316L об'ємом 200 л, 400 л, 600 л і 1200 л.

Результати й обговорення. Для визначених критичних параметрів технологічного процесу отримання продукту проводили валідаційні випробування, які

Таблиця 1. Методики досліджень на кожній стадії виробничого процесу

\begin{tabular}{|l|l|}
\hline \multicolumn{1}{|c|}{ Назва стадії } & \multicolumn{1}{c|}{ Методики дослідження } \\
\hline Підготовка сировина & $\begin{array}{l}\text { Методики відбору і контролю проб } \\
\text { відповідно до специсрікації на сировину і вихідні матеріали }\end{array}$ \\
\hline $\begin{array}{l}\text { Отримання маси для } \\
\text { таблетування }\end{array}$ & $\begin{array}{l}\text { Зважування на електронних вагах } \\
\text { Візуальний контроль параметрів техпроцесу } \\
\text { Методики контролю показників якості відповідно до специсікації на таблетмасу }\end{array}$ \\
\hline зберігання таблетмаси & $\begin{array}{l}\text { Незалежний контроль техпроцесу на відповідність дій персоналу вимогам технологіч- } \\
\text { ного регламенту } \\
\text { Візуальний контроль параметрів техпроцесу } \\
\text { Методики контролю показників якості відповідно до специсрікації на таблетмасу після } \\
\text { зберігання }\end{array}$ \\
\hline Таблетування & $\begin{array}{l}\text { Незалежний контроль техпроцесу на відповідність дій персоналу вимогам } \\
\text { технологічного регламенту } \\
\text { Візуальний контроль параметрів техпроцесу } \\
\text { Методики контролю показників якості відповідно до специсрікації на нерозсрасовані } \\
\text { таблетки }\end{array}$ \\
\hline $\begin{array}{l}\text { Нанесення плівкової } \\
\text { оболонки на таблетки- } \\
\text { ядра }\end{array}$ & $\begin{array}{l}\text { Незалежний контроль техпроцесу на відповідність дій персоналу вимогам } \\
\text { техногічного регламенту } \\
\text { Візуальний контроль параметрів техпроцесу } \\
\text { Методики контролю показників якості відповідно до специфрікації на нерозсрасовані } \\
\text { таблетки, вкриті оболонкою }\end{array}$ \\
\hline
\end{tabular}

ISSN 2312-0967. Фармацевтичний часопис. 2017. № 4 
дозволяють визначити допустимі межі відхилення цих параметрів.

Схему точок відбору проб на стадії приготування таблетмаси при проведені валідації процесу представлено на рисунку 1.

Результати аналізів на стадії приготування таблетмаси у пробах із контейнера представлено на рисунку 2.
Фармацевтична технологія, біофармація, гомеопатія Pharmaceutical technology, biopharmacy, homeopathy

У процесі валідації технологічного процесу виробництва таблеток «Уронефрон» отримано результати для трьох валідаційних серій препарату. Після підтвердження статистичної відповідності валідаційних серій дані об'єднували. Результати наведено в таблиці 2.

Результати, отримані в ході проведення валідаційних робіт, знаходяться в межах встановлених критеріїв прийнятності.

\section{1-а вісь відбору}

1 - Лівий верх

2-а вісь відбору

2 Верх ззаду 3 - Середина ззаду

3-а вісь відбору

4 - Центр зверху 5 - Центр середина

6 - Центр знизу 7 - Центр розвантажувальний люк

\section{4-а вісь відбору}

8 - Верх спереду 9 - Середина спереду

5-а вісь відбору

$10-$ Правий верх

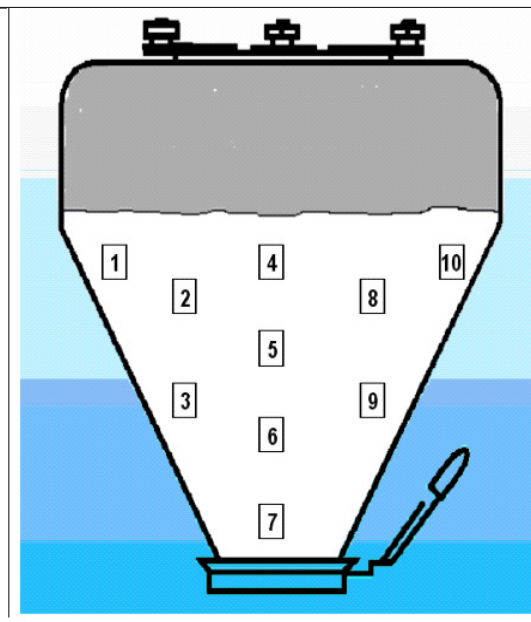

Рис. 1. Схема точок відбору проб із контейнера.

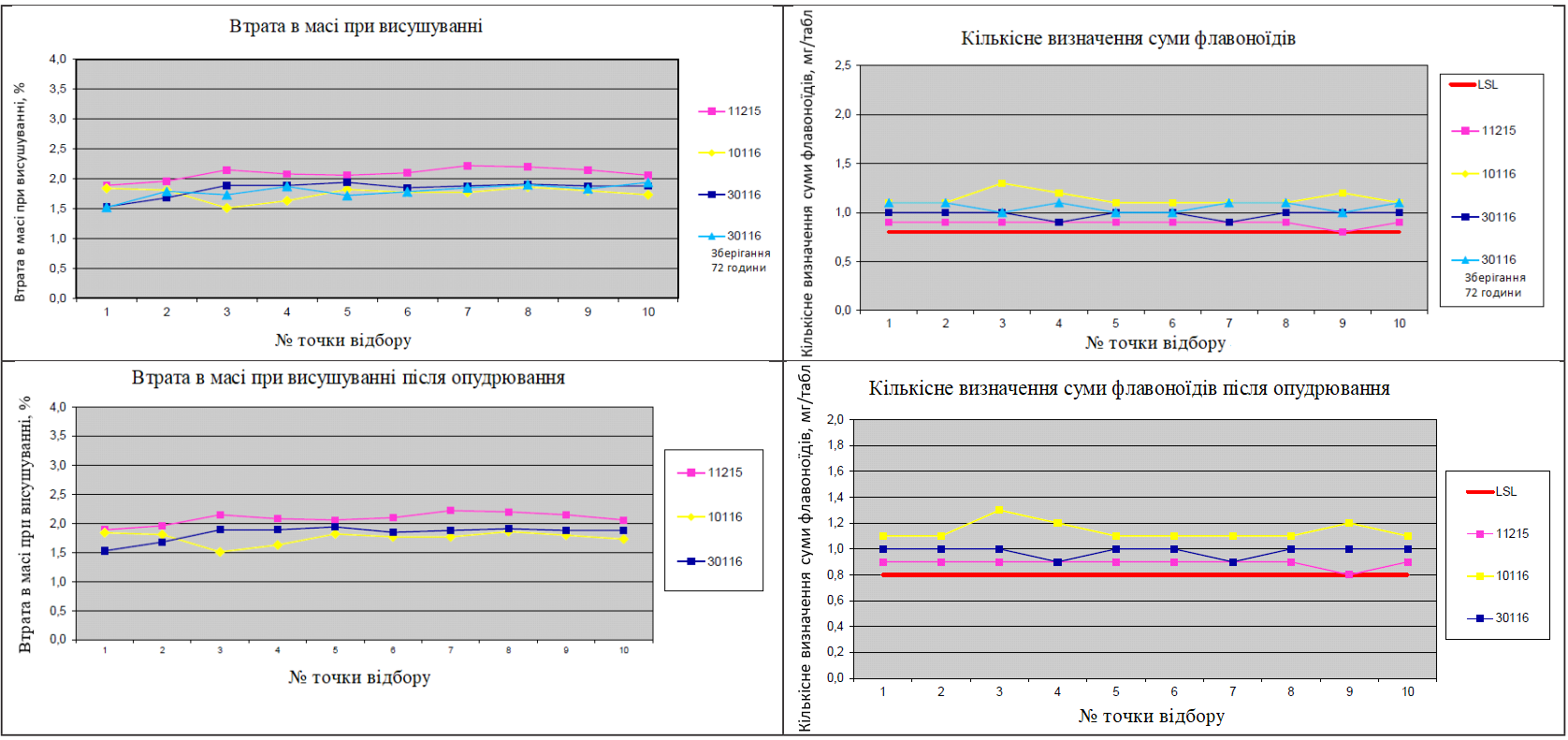

Рис. 2. Результати аналізу таблетмаси.

Таблиця 2. Моніторинг критичних показників якості напівпродукту

\begin{tabular}{|c|c|c|c|c|}
\hline $\begin{array}{c}\text { Стадія / } \\
\text { операція } \\
\text { процесу }\end{array}$ & Контрольований показник & Критерій прийнятності & Результат & Відповідність \\
\hline 1 & 2 & 3 & 4 & 5 \\
\hline \multicolumn{5}{|c|}{ Підготовка сировини } \\
\hline & $\begin{array}{l}\text { Втрата в масі при } \\
\text { висушуванні } \\
\text { (Сухий екстракт з } 9 \text { рослин) }\end{array}$ & Не більше 6,0% & $(1,8-3,0) \%$ & Відповідає \\
\hline
\end{tabular}

ISSN 2312-0967. Pharmaceutical review. 2017. № 4 
Фармацевтична технологія, біофармація, гомеопатія Pharmaceutical technology, biopharmacy, homeopathy

Продовження табл. 2

\begin{tabular}{|c|c|c|c|c|c|c|}
\hline 1 & 2 & \multicolumn{2}{|r|}{3} & \multicolumn{2}{|r|}{4} & 5 \\
\hline & $\begin{array}{l}\text { Вода } \\
\text { (Лактоза моногідрат 200)) }\end{array}$ & \multicolumn{2}{|l|}{$(4,5-5,5) \%$} & \multicolumn{2}{|c|}{$(5,07-5,18) \%$} & Відповідає \\
\hline & $\begin{array}{l}\text { Втрата в масі при } \\
\text { прожарюванні } \\
\text { (Аеросил) }\end{array}$ & \multicolumn{2}{|c|}{ Не більше 5,0% } & \multicolumn{2}{|c|}{$(2,6-2,7) \%$} & Відповідає \\
\hline & \begin{tabular}{|l|} 
Втрата в масі при \\
висушуванні (МКЦ 102) \\
\end{tabular} & \multicolumn{2}{|c|}{ Не більше 7,0% } & \multicolumn{2}{|l|}{$1,0 \%$} & Відповідає \\
\hline & $\begin{array}{l}\text { Втрата в масі при } \\
\text { висушуванні (магнію } \\
\text { стеарат) }\end{array}$ & \multicolumn{2}{|c|}{ Не більше 6,0 \% } & \multicolumn{2}{|c|}{$(1,5-1,6) \%$} & Відповідає \\
\hline & \multirow{3}{*}{$\begin{array}{l}\text { Розмір часток } \\
\text { (сухий екстракт з } 9 \\
\text { рослин) }\end{array}$} & \multirow{3}{*}{\multicolumn{2}{|c|}{ Інфрормативна величина }} & $\mathrm{D}(10)$ & $(28,7-33,2)$ мкм & Відповідає \\
\hline & & & & $\mathrm{D}(50)$ & $(97,9-100)$ мкм & \\
\hline & & & & $\mathrm{D}(90)$ & (200-208) мкм & \\
\hline & \multirow{3}{*}{$\begin{array}{l}\text { Розмір часток } \\
\text { (Магнію стеарат) }\end{array}$} & \multirow{3}{*}{\multicolumn{2}{|c|}{ Інформативна величина }} & $\mathrm{D}(10)$ & $(0,876-1,65)$ мкм & Відповідає \\
\hline & & & & $\mathrm{D}(50)$ & $(3,80-7,83)$ мкм & \\
\hline & & & & $\mathrm{D}(90)$ & $(15,5-18,8)$ мкм & \\
\hline \multicolumn{7}{|c|}{ Отримання маси для таблетування } \\
\hline \multirow[t]{10}{*}{$\begin{array}{l}\text { Опудрю- } \\
\text { вання }\end{array}$} & $\begin{array}{l}\text { Втрата в масі при } \\
\text { висушуванні }\end{array}$ & \multicolumn{2}{|c|}{ Інфрормативна величина } & \multicolumn{2}{|c|}{$(1,51-2.22) \%$} & Відповідає \\
\hline & $\begin{array}{l}\text { Кількісне визначення суми } \\
\text { фрлавоноїдів }\end{array}$ & \multicolumn{2}{|c|}{$\begin{array}{l}\text { Не менше 0,8 \% у перерахунку } \\
\text { на рутин }\end{array}$} & \multicolumn{2}{|c|}{$(0,8-1,3) \%$} & Відповідає \\
\hline & \multirow[t]{4}{*}{ Насипна густина } & 0 ударів & $(0,350-0,750)$ г/мл & \multicolumn{2}{|c|}{$(0,476-0,499)$ г/мл } & Відповідає \\
\hline & & 10 ударів & \multirow{3}{*}{$\begin{array}{l}\text { Інорормативна } \\
\text { величина }\end{array}$} & \multicolumn{2}{|c|}{$(0,506-0,520)$ г/мл } & \\
\hline & & 500 ударів & & \multicolumn{2}{|c|}{$(0,576-0,613)$ г/мл } & \\
\hline & & 1250 ударів & & \multicolumn{2}{|c|}{$(0,591-0,629)$ г/мл } & \\
\hline & Сипучість & \multicolumn{2}{|l|}{$(1,0-8,0)$ г/c } & \multicolumn{2}{|c|}{$(2,6-2,7)$ г/c } & Відповідає \\
\hline & Кут відкосу & $(30-50)^{\circ}$ & & $(40,1$ & $0,3)^{\circ}$ & Відповідає \\
\hline & Фракційний склад & Менше 2 мм & $100 \%$ & $100 \%$ & & Відповідає \\
\hline & & Менше 125 мкм & Не менше $20 \%$ & $(38,45$ & $41,29) \%$ & \\
\hline & & Зберіганн & чя таблетмаси & & & \\
\hline & $\begin{array}{l}\text { Втрата в масі при } \\
\text { висушуванні }\end{array}$ & Інформативна & величина & $(1,52$ & $94) \%$ & Відповідає \\
\hline & $\begin{array}{l}\text { Кількісне визначення суми } \\
\text { фрлавоноїдів }\end{array}$ & $\begin{array}{l}\text { Не менше 0,8 } \\
\text { на рутин }\end{array}$ & \% у перерахунку & $(1,0-1$ & $\%$ & Відповідає \\
\hline & Насипна густина & 0 ударів & $(0,350-0,750)$ г/мл & 0,479 & & Відповідає \\
\hline & & 10 ударів & & 0,510 & & \\
\hline & & 500 ударів & Інорормативна & 0,586 & & \\
\hline & & 1250 ударів & & 0,601 & & \\
\hline & Сипучість & $(1,0-8,0)$ г/с & & 2,8 г/c & & Відповідає \\
\hline & Кут відкосу & $(30-50)^{\circ}$ & & $40,1^{\circ}$ & & Відповідає \\
\hline & Фракційний склад & Менше 2 мм & $100 \%$ & $100 \%$ & & Відповідає \\
\hline & & Менше 125 мкм & Не менше $20 \%$ & 40,53 & & \\
\hline & Мікробіологічна чистота & Аеробні м/о & $1000 \mathrm{KOE} / \Gamma$ & Менш & $100 \mathrm{KOE} / \Gamma$ & Відповідає \\
\hline & & $\begin{array}{l}\text { Дріжджові і } \\
\text { цвілеві гриби }\end{array}$ & $100 \mathrm{KOE} / \Gamma$ & Менш & $10 \mathrm{KOE} / \Gamma$ & \\
\hline & & $\begin{array}{l}\text { Escherichia } \\
\text { coli }\end{array}$ & Відсутні & 0 & & \\
\hline
\end{tabular}

ISSN 2312-0967. Фармацевтичний часопис. 2017. № 4 
Фармацевтична технологія, біофармація, гомеопатія Pharmaceutical technology, biopharmacy, homeopathy

Продовження табл. 2

\begin{tabular}{|c|c|c|c|c|}
\hline 1 & 2 & 3 & 4 & \multirow[b]{3}{*}{ Відповідає } \\
\hline \multicolumn{4}{|c|}{ Таблетування } & \\
\hline & $\begin{array}{l}\text { Середня маса таблеток- } \\
\text { ядер }\end{array}$ & $\begin{array}{l}(0,4275-0,4725) г \\
R S D \leq 5 \% \\
C p K \geq 1\end{array}$ & $\begin{array}{l}(0,4469-0,4593) г \\
\text { RSD }=1,56 \% \\
\text { CpK }=1,35\end{array}$ & \\
\hline & $\begin{array}{l}\text { Стійкість до } \\
\text { роздавлювання }\end{array}$ & Не менше $40 \mathrm{H}$ & $(56-100) \mathrm{H}$ & Відповідає \\
\hline & Середня висота & Не більше 5,4 мм & $(4,8-5,0) \mathrm{MM}$ & Відповідає \\
\hline & Середній діаметр & $(10,8-11,2)$ мм & $11,0 \mathrm{~mm}$ & Відповідає \\
\hline & Розпадання & Не більше 20 мін. & (12-18) мін. & Відповідає \\
\hline \multicolumn{5}{|c|}{ Нанесення плівкової оболонки на таблетки-ядра } \\
\hline & $\begin{array}{l}\text { Середня маса таблеток, } \\
\text { вкритих плівковою } \\
\text { оболонкою }\end{array}$ & $\begin{array}{l}(0,449-0,496) \text { г } \\
R S D \leq 5 \%\end{array}$ & $\begin{array}{l}(0,468-0,476)\ulcorner \\
\operatorname{RSD}=(0,25-0,46) \%\end{array}$ & Відповідає \\
\hline & Розпадання & Не більше 30 мін. & (15-30) мін. & Відповідає \\
\hline & $\begin{array}{l}\text { Кількісне визначення суми } \\
\text { орлавоноїдів }\end{array}$ & $\begin{array}{l}\text { Не менше 0,8 \% в перерахунку } \\
\text { на рутин }\end{array}$ & $(0,8-1,0) \%$ & Відповідає \\
\hline
\end{tabular}

Висновок. Валідація процесу виробництва таблеток «Уронефррон» підтвердила кваліфікацію виробничого персоналу і дотримання ним прописаних параметрів; показала, що технологічне обладнання ділянки в змозі забезпечити відтворюваність параметрів технологічного процесу виробництва, що призводить до очікуваного рівня якості напівпродукту і готової продукції; продемонструвала відтворюваність і стандартність показників якості напівпродукту і готової продукції відповідно до нормативної документації.

\section{ВАЛИДАЦИЯ ПРОИЗВОДСТВА ТАБЛЕТОК «УРОНЕФРОН»}

\section{В. Л. Шевина ${ }^{1}$, Н. В. Хохленкова ${ }^{2}$, М. И. Борщевская ${ }^{1}$ В. А. Коноваленко ${ }^{1}$}

ПАО «Фармак»${ }^{1}$, Киев

Национальный фрармацевтический университет², Харьков

v.shevina@farmak.ua

Цель работы. Предоставить документальные доказательства, которые подтвердят, что процесс производства препарата таблеток «Уронефрон», покрытых пленочной оболочкой, приводит к получению продукта установленного качества.

Материалы и методы. Валидационные исследования проводились на 3 сериях препарата. Валидация процесса производства таблеток «Уронесрон» проведена на всех стадиях технологического процесса и определены критические параметры, а именно: подготовка сырья, получение массы для таблетирования, выдержка таблетмассы, таблетирование, нанесение пленочной оболочки на таблетки-ядра.

Результаты и обсуждение. Для определенных критических параметров технологичного процесса получения продукта проводили валидационные испытания, которые позволяют определить допустимые пределы отклонения этих параметров.

Результаты проведения валидационных испытаний на каждой стадии технологического процесса изготовления таблеток «Уронефрон» соответствуют критериям приемлемости.

Вывод. Валидация процесса производства таблеток «Уронефрон» подтвердила квалификацию производственного персонала и соблюдение прописанных параметров; показала, что технологическое оборудование на производственном участке в состоянии обеспечить воспроизводимость параметров технологического процесса производства, что приводит к ожидаемому уровню качества полупродукта и готовой продукции; продемонстрировала воспроизводимость и стандартность показателей качества полупродукта и готовой продукции в соответствии с нормативной документацией.

Ключевые слова: валидационные испытания; критерии приемлемости; технологический процесс; таблетки «Уронефрон».

ISSN 2312-0967. Pharmaceutical review. 2017. № 4 
Фармацевтична технологія, біофармація, гомеопатія

Pharmaceutical technology, biopharmacy, homeopathy

\title{
MANUFACTURE VALIDATION OF TABLETS "URONEFRON"
}

\author{
V. L. Shevina ${ }^{1}$, N. V. Khokhlenkova ${ }^{2}$, M. I. Borshchevska ${ }^{1}$, V. A. Konovalenko ${ }^{1}$ \\ JSC «Farmak» ${ }^{1}$, Kyiv \\ National University of Pharmacy², Kharkiv \\ v.shevina@farmak.ua
}

The aim of the work. Providing the documentary evidence, which will confirm that «Uronefron» manufacturing process in the form of film-coated tablets yields the manufacture of the product with the established quality.

Materials and Methods. Validation studies were performed on 3 product batches.

Process validation for «Uronefron» tablets was conducted on all stages of production process defining the critical parameters i.e. raw material preparation, production of tablet blend, hold of tablet blend, tableting, film-coating of tablet cores.

Results and Discussion. For the defined critical process parameters of the product manufacture, the validation tests, which permit to define the allowable excursion limits for these parameters, were performed.

The results for validation tests at each stage of «Uronefron» production process meet the eligibility criteria.

Conclusions. Process validation for «Uronefron» tablets has confirmed the qualification of the production personnel and adherence to the prescribed parameters; has demonstrated that the production equipment of the site is capable of reproducing the parameters of manufacturing process that will yield the expected quality level of the intermediate product and finished products; has demonstrated the reproducibility and standardness of the quality attributes for intermediate product and finished product, according to regulatory documentation.

Key words: validation test; acceptance criteria; technological process, «Uronefron» tablets.

\section{Список літератури}

1. Лікарські засоби. Належна виробнича практика: настанова СТ-Н МОЗУ 42-4.0:2015. - К. : «Морион», 2015.

2. Шкляєв С. А. Обґрунтування та встановлення критерію прийнятності при валідації технологічних процесів на фрармацевтичному підприємстві / С. А. Шкляєв // Фармацевтичний журнал. - 2012. - С. 43-46.

3. Валідація процесів. Належна виробнича практика: настанова СТ-Н МОЗУ 42-3.5:2016. - К. : «Морион», 2016. - C. 23.

4. Системи управління якістю. Вимоги: (ISO 9001:2000, IDT): ДСТУ ISO 9001-2001. - [На заміну ДСТУ ISO $9001-$ 95, ДСТУ ISO 9002-95, ДСТУ ISO 9003-95; чинний від 2001-06-27]. - К. : Держспоживстандарт України. - 2001. - С. 33 - (Національний стандарт України).

5. Бармина А. Рекомендации профессионалов. Квалисрикация и валидация в свете требований GMP / А. Бармина // Еженедельник Аптека. - 2008. - № 17 (638). - C. 84-85.

6. Final Concept Paper. Q 10: Pharmaceutical Quality Systems dated 9 September 2005. - ICH SC, 10 November 2005. - Режим доступу до сайту: http://www.ich.org.

\section{References}

1. Medicines. Good manufacturing practice. [Лікарські засоби. Належна виробнича практика: настанова СТ-Н MO3У 42-4.0:2016] Kyiv: Morion, 2016. Ukrainian.

2. Shklayev SA. [Substantiation and establishment of the eligibility criterion for the validation of technological processes in the pharmaceutical enterprise]. Farmatsev zhurn., 2012: 43-6. Ukrainian

3. Validation of processes. Good manufacturing practice. [Валідація процесів. Належна виробнича практика:
7. Good manufacturing practice for pharmaceutical products: Main principles./ World Heals Organization technical Report Series. - 2003. - № 908. - Mode of access: http:// www.who.int

8. Good manufacturing practice for sterile pharmaceutical products. In: WHO Expert Committee on Specification for Pharmaceutical Preparations. Thirty-sixth report. WHO Technical Report Series, \# 902. Annex 6 - World Heals Organization. - 2002. $-220 \mathrm{p}$.

9. PIC/S Recommendations PI 006-3 «Validation master plan installation and operational qualification non-sterile process validation; Cleaning validation». -2007. - P. 26. Mode of access: http://www.picscheme.org/index.php.

10. PIC/S Recommendations PI 007-3 «On the validation of aseptic processes». - 2007. - P. 17 - Mode of access: http://www.picscheme.org/index.php.

11. Шестопал О. А. Розробка підходів до валідації технологічного процесу виробництва стерильних лікарських засобів / О.А.Шестопал, Ю. В. Підпружников // Управління, економіка та забезпечення якості в фармацію. - 2008. - Т. І, № 2.

ISSN 2312-0967. Фармацевтичний часопис. 2017. № 4

настанова СТ-H МОЗУ] 42-3.5:2016. - Kyiv: Morion, 2016. Ukrainian.

4. Quality management systems. Requirements [Системи управління якістю. Вимоги]: (ISO 9001: 2000, IDT): DSTU ISO 9001-2001. [To replace DSTU ISO 9001-95, DSTU ISO 9002-95, DSTU ISO 9003-95; effective from 2001-0627]. Kyiv: Derzhspozhyvstandart of Ukraine 33 (National standard of Ukraine). Ukrainian.

5. Barmina A. Recommendations of professionals. Quali- 
Фармацевтична технологія, біофармація, гомеопатія Pharmaceutical technology, biopharmacy, homeopathy

fication and Validation in the light of the requirements of GMP. Yezhenedelnik Apteka. 2008;17(638): 84-5. Russian. 6. Final Concept Paper. Q 10: Pharmaceutical quality systems dated 9 September 2005. - ICH SC, 10 November 2005. - Available from: http://www.ich.org.

7. Good manufacturing practice for pharmaceutical products: main principles. World Heals Organization technica Report Series. 2003;908. - Available from: http://www.who. int

8. Good manufacturing practice for sterile pharmaceutical products. In: WHO Expert Committee on Specification for Pharmaceutical Preparations. Thirty-sixth report. WHO
Technical Report Series, \# 902. Annex 6 - World Heals Organization. 2002: 220.

9. PIC/S Recommendations PI 006-3 «Validation master plan installation and operational qualification non-sterile process validation; Cleaning validation». 2007: 26. - Available from: http://www.picscheme.org/index.php.

10. PIC/S Recommendations PI 007-3 «On the validation of aseptic processes». 2007: 17. - Available from: http://www. picscheme.org/index.php.

11. Shestopal OA, Pidpruzhnikov YuV. [Development of approaches to validation of the process of production of sterile medicinal products]. Upravlinnia, ekon. ta zabezpech. yakos. v farmatsii. 2008:I(2).

Отримано 14.09.2017

ISSN 2312-0967. Pharmaceutical review. 2017. № 4 